\title{
Microbiotic crusts on soil, rock and plants: neglected major players in the global cycles of carbon and nitrogen?
}

\author{
W. Elbert ${ }^{1}$, B. Weber ${ }^{2}$, B. Büdel ${ }^{2}$, M. O. Andreae ${ }^{1}$, and U. Pöschl ${ }^{1}$ \\ ${ }^{1}$ Max Planck Institute for Chemistry, Biogeochemistry Department, P. O. Box 3060, \\ 55020, Mainz, Germany \\ ${ }^{2}$ University of Kaiserslautern, Dept. Biology, Plant Ecology and Systematics, P. O. Box 3049, \\ 67653 Kaiserslautern, Germany
}

Received: 17 June 2009 - Accepted: 6 July 2009 - Published: 14 July 2009

Correspondence to: W. Elbert (elbert@mpch-mainz.mpg.de)

Published by Copernicus Publications on behalf of the European Geosciences Union.

6983

\begin{abstract}
Microbiotic crusts consisting of bacteria, fungi, algae, lichens, and bryophytes colonize most terrestrial surfaces, and they are able to fix carbon and nitrogen from the atmosphere. Here we show that microbiotic crusts are likely to play major roles in the global 5 biogeochemical cycles of carbon and nitrogen, and we suggest that they should be further characterized and taken into account in studies and models of the Earth system and climate.

For the global annual net uptake of carbon by microbiotic crusts we present a first estimate of $\sim 3.6 \mathrm{Pg} \mathrm{a}^{-1}$. This uptake corresponds to $\sim 6 \%$ of the estimated global net 10 carbon uptake by terrestrial vegetation (net primary production, NPP: $\sim 60 \mathrm{Pg} \mathrm{a}^{-1}$ ), and it is of the same magnitude as the global annual carbon turnover due to biomass burning. The estimated rate of nitrogen fixation by microbiotic crusts $\left(\sim 45 \mathrm{Tg} \mathrm{a}^{-1}\right)$ amounts to $\sim 40 \%$ of the global estimate of biological nitrogen fixation $\left(107 \mathrm{Tg} \mathrm{a}^{-1}\right)$. With regard to Earth system dynamics and global change, the large contribution of microbiotic

15 crusts to nitrogen fixation is likely to be important also for the sequestration of $\mathrm{CO}_{2}$ by terrestrial plants $\left(\mathrm{CO}_{2}\right.$ fertilization), because the latter is constrained by the availability of fixed nitrogen.
\end{abstract}

\section{Introduction}

Microbiotic crusts consisting of bacteria, fungi, algae, lichens, and bryophytes colonize 20 most terrestrial surfaces (Figs. 1 and S1, see http://www.biogeosciences-discuss.net/ 6/6983/2009/bgd-6-6983-2009-supplement.pdf). In the form of biological soil crusts (BSC) and rock crusts (BRC), they inhabit soils and rocks in arid and semiarid regions as well as in other climatic zones (Friedmann, 1980; Friedmann et al., 1993; MatthesSears et al., 1997; Kappen et al., 1998; Büdel, 1999; Kurina and Vitousek, 1999; Zaady et al., 2000; Büdel, 2002; Belnap, 2003; Belnap and Lange, 2003; Rascher et al., 2003; Boison et al., 2004; Hoppert et al., 2004; Walker et al., 2005; Bhatnagar et al., 2008; 
Büdel et al., 2008; Schmidt et al., 2008; Weber et al., 2008; Wilske et al., 2008). Microbiotic crusts also cover a large proportion of the surface of terrestrial plants, including stems and branches of trees (epiphytic crusts) as well as tree leaves (epiphyllic crusts) (Ruinen, 1956; Last and Deighton, 1965; Berrie and Eze, 1975; Bentley, 1987; Sheri5 dan, 1991a; Peveling et al., 1992; Coley et al., 1993; Freiberg, 1999; Büdel et al., 2000; Freiberg and Freiberg, 2000; Sillett and Rambo, 2000; Campbell and Coxson, 2001; Lücking and Matzer, 2001; Anthony et al., 2002; Radies and Coxson, 2004; Wanek and Portl, 2005; Lakatos et al., 2006; Cáceres et al., 2007). For the sake of brevity, we shall include both types in the term "epiphytic crusts" (EPC).

10 It is well known that these communities are able to fix carbon and nitrogen from the atmosphere (Mayland and McIntosh, 1966; Jones, 1970; Bentley, 1987; Beymer and Klopatek, 1991; Lange et al., 1992; Freiberg, 1998; Evans and Johansen, 1999; Juhász et al., 2002; Belnap, 2003; Boison et al., 2004; Yeager et al., 2007). They produce biomass and they release $\mathrm{C}$ - and $\mathrm{N}$-containing compounds like carbohydrates

15 and amino acids to the surrounding ecosystem (Boucher and Nash, 1990; Beymer and Klopatek, 1991; Coxson et al., 1992; Belnap and Lange, 2003; Turetsky, 2003; Dojani et al., 2007; Schmidt et al., 2008). However, their contribution to the global cycles of carbon and nitrogen has not yet been quantified. In this study we calculate and present first estimates of the global annual net uptake of $\mathrm{CO}_{2}$ and fixation of $\mathrm{N}_{2}$ by microbiotic crusts.

\section{Methods}

From earlier studies of microbiotic crusts we have compiled as many estimates of annual uptake fluxes and surface coverage values as we could find in a thorough literature search. For global upscaling we used median values of the flux data in combination with global estimates of the surface areas of (semi)arid regions and plants, respectively. All used data and references are tabulated in the Appendix (Tables A1-A9).

Note that we used median rather than arithmetic mean values in order to obtain 6985

conservative estimates. The median values were generally in fair agreement with the corresponding arithmetic mean values, and the relative standard errors of the mean values (relative standard deviation divided by the square root of the number of data points) ranged up to $\sim 80 \%$. Thus we assume that the presented global estimates are 5 uncertain by a factor of $\sim 2$.

\section{Results and discussion}

For the net uptake of carbon by soil crusts in arid and semi-arid regions, we obtained a median flux of $\sim 16 \mathrm{~g} \mathrm{~m}^{-2} \mathrm{a}^{-1}$ (Table A1a). Multiplication with the global dry-land area (Table A2) yields an estimate of $\sim 1.0 \mathrm{Pg} \mathrm{a}^{-1}$ for the net uptake of carbon by BSC

10 in arid and semi-arid regions. With regard to the carbon balance, the reported net uptake values (photosynthesis minus respiration) should be considered as net primary production (NPP) (Chapin et al., 2006).

Soil crusts occur also in non-vegetated gaps of grasslands, tundra and steppe formations, sparsely vegetated grounds of temperate and boreal forests, burnt forest areas,

15 formerly permafrosted soils, and previously ice-covered glacier grounds (Forman and Dowden, 1977; Eversman and Horton, 2004; Schmidt et al., 2008). The median net carbon uptake by soil crusts in these areas is $\sim 23 \mathrm{~g} \mathrm{~m}^{-2} \mathrm{a}^{-1}$ (Table A1b), and that by rock crusts is $\sim 8 \mathrm{~g} \mathrm{~m}^{-2} \mathrm{a}^{-1}$ (Table A1c). Because the global area colonized by non-arid BSC and by rock crusts are not known, we cannot provide a quantitative estimate for their carbon uptake, but obviously any non-zero flux will increase the total amount of carbon taken up by biological crusts to more than the value of $\sim 1 \mathrm{Pga}^{-1}$ given above for arid and semiarid soil crusts alone.

For the net uptake of carbon by epiphytic crusts, we obtained a median flux of $\sim 28 \mathrm{~g} \mathrm{~m}^{-2} \mathrm{a}^{-1}$ (Table A3). Multiplication with the corresponding global surface areas

25 of evergreen leaves, branches and stems of trees, and tropical lianas (Tables A4, A5, and A7), assuming coverages of $30-50 \%$ (Tables $A 6$ and A7), yields an estimate of $\sim 2.6 \mathrm{Pg} \mathrm{a}^{-1}$ for the global net uptake of carbon by epiphytic crusts (Table A7). 
The total value of $\sim 3.6 \mathrm{Pg} \mathrm{a}^{-1}$ estimated for the global net uptake of carbon by microbiotic crusts corresponds to $\sim 6 \%$ of the estimated global net carbon uptake by terrestrial vegetation (net primary production, NPP: $\sim 60 \mathrm{Pg} \mathrm{a}^{-1}$, Running et al., 2004). To put this flux into perspective: it is of the same magnitude as the global annual carbon 5 turnover due to biomass burning, which has been estimated at $3.6 \mathrm{Pga}^{-1}$ (Andreae and Merlet, 2001).

The reported values of biomass in microbiotic crusts are in the range of $1-1200 \mathrm{~g} \mathrm{~m}^{-2}$ (dry mass) with median values of $260 \mathrm{~g} \mathrm{~m}^{-2}$ for soil crusts and $130 \mathrm{~g} \mathrm{~m}^{-2}$ for epiphytic crusts (Table A8). By multiplication of these values with the global areas of dry-lands

10 and forests/shrubs, respectively (Tables A2 and A7) we obtain global estimates of $\sim 17 \mathrm{Pg}$ for the biomass of BSC in arid and semi-arid regions and $\sim 6 \mathrm{Pg}$ for the biomass of EPC on evergreen leaves, on branches and stems of trees, and on tropical lianas. The total of $\sim 23 \mathrm{Pg}$ estimated for the global dry biomass of microbiotic crusts corresponds to $\sim 10 \mathrm{Pg}$ of carbon (conversion factor $\sim 2$ ) (Whitman et al., 1998), and thus

15 to $\sim 2 \%$ of the estimated global mass of carbon in terrestrial vegetation $(470-650 \mathrm{Pg})$ (Prentice et al., 2001).

Microbiotic crusts do not only fix carbon, but are also able to assimilate atmospheric nitrogen. The reported average fluxes of nitrogen fixation are in the range of $0.1-10 \mathrm{~g} \mathrm{~m}^{-2} \mathrm{a}^{-1}$ (Table A9). With the median values of $\sim 0.4 \mathrm{~g} \mathrm{~m}^{-2} \mathrm{a}^{-1}$ for BSC and $20 \sim 0.35 \mathrm{~g} \mathrm{~m}^{-2} \mathrm{a}^{-1}$ for EPC (Table A9) and using the same surface area values as above, we obtain global estimates of $\sim 30 \mathrm{Tg} \mathrm{a}^{-1}$ and $\sim 15 \mathrm{Tg} \mathrm{a}^{-1}$ for nitrogen fixation by BSC and EPC, respectively. Thus, the total rate of nitrogen fixation by microbiotic crusts $\left(\sim 45 \mathrm{Tg} \mathrm{a}^{-1}\right)$ appears to be a major contribution to global biological nitrogen fixation, which is estimated to be about $107 \mathrm{Tg} \mathrm{a}^{-1}$ (Galloway, 2005). Note that nitrogen fixation

25 by microbiotic crusts is likely to be important also for the sequestration of $\mathrm{CO}_{2}$ by terrestrial plants $\left(\mathrm{CO}_{2}\right.$ fertilization), because the latter is constrained by the availability of fixed nitrogen (Reich et al., 2006).

6987

\section{Conclusions}

Overall, our calculations suggest that microbiotic crusts on soil, rock, and plants are major players in the global biogeochemical cycles of carbon and nitrogen and should thus be considered in climate and Earth system models. Regional and seasonal pat5 terns as well as long-term trends regarding their diversity, abundance and gas exchange with the atmosphere need to be better characterized for a full mechanistic and quantitative understanding of the influence of the biosphere on climate.

\section{Appendix A}

See Tables A1-A9.

10 Acknowledgements. This work has been funded by the Max Planck Society (W. E., M. O. A., U. P.) and by the German Research Foundation (B. B., B. W.). Thanks to J. Steinkamp and E. Falge for support in the determination of geographical surface areas and leaf area indices, respectively.

15 The service charges for this open access publication have been covered by the Max Planck Society.

\section{References}

Ajtay, G. L., Ketner, P., and Duvigneaud, P.: Terrestrial primary production and phytomass, in: The Global Carbon Cycle, SCOPE 13, edited by: Bolin, B., Degens, E. T., and Ketner, P., John Wiley \& Sons, New York, 129-182, 1979.

André, J., Gourbière, F., and Bardin, R.: Epiphytic lichens and microfungi associated to needles in a fir forest of Massif Central, Oecologia Plantarum, 10, 13-23, 1975.

Andreae, M. O. and Merlet, P.: Emission of trace gases and aerosols from biomass burning, Global Biogeochem. Cy., 15, 955-966, 2001. 
Anthony, P. A., Holtum, J. A. M., and Jackes, B. R.: Shade acclimation of rainforest leaves to colonization by lichens, Funct. Ecol., 16, 808-816, 2002.

Antoine, M. E.: An ecophysiological approach to quantifying nitrogen fixation by Lobaria oregana, Bryologist, 107, 82-87, 2004.

5 Arora, V. K. and Boer, G. J.: A parameterization of leaf phenology for the terrestrial ecosystem component of climate models, Glob. Change Biol., 11, 39-59, 2005.

Asner, G. P., Archer, S., Hughes, R. F., Ansley, R. J., and Wessman, C. A.: Net changes in regional woody vegetation cover and carbon storage in Texas Drylands, 1937-1999, Glob. Change Biol., 9, 316-335, 2003.

10 Becker, V. E.: Nitrogen fixing lichens in forests of the southern Appalachian Mountains of North Carolina, Bryologist, 83, 29-39, 1980.

Bell, R. A. and Sommerfeld, M. R.: Algal biomass and primary production within a temperate zone sandstone, Am. J. Bot., 74, 294-297, 1987.

Belnap, J., Kaltenecker, J. H., Rosentreter, R., Williams, J., Leonard, S., and Eldridge, D.: Bio-

15 logical soil crusts: ecology and management, Technical reference 1730-2, US Departement of the Interior, Denver, 1-118, 2001.

Belnap, J.: Nitrogen fixation in biological soil crusts from southeast Utah, USA, Biol. Fert. Soils, $35,128-135,2002$.

Belnap, J.: The world at your feet: desert biological soil crusts, Frontiers in Ecology and the Environment, 1, 181-189, 2003.

Belnap, J. and Lange, O. L.: Structure and functioning of biological soil crusts: synthesis, in: Biological soil crusts: structure, function, and management, 2nd ed., edited by: Belnap, J. and Lange, O. L., Ecological Studies, Springer-Verlag, Berlin Heidelberg, 471-479, 2003.

Benson, S. and Coxson, D. S.: Lichen colonization and gap structure in wet-temperate rainforests of northern interior British Columbia, Bryologist, 105, 673-692, 2002.

Bentley, B. L.: Nitrogen fixation by epiphylls in a tropical rainforest, Ann. Mo. Bot. Gard., 74, 234-241, 1987.

Bernstein, M. E. and Carroll, G. C.: Microbial populations on Douglas fir needle surfaces, Microbial Ecol., 4, 41-52, 1977.

30 Berrie, G. K. and Eze, J. M. O.: Relationship between an epiphyllous liverwort and host leaves, Ann. Bot.-London, 39, 955-963, 1975.

Beymer, R. J. and Klopatek, J. M.: Potential contribution of carbon by microphytic crusts in pinyon-juniper woodlands, Arid Soil Res. Rehab., 5, 187-198, 1991.

6989

Bhatnagar, A., Makandar, M. B., Garg, M. K., and Bhatnagar, M.: Community structure and diversity of cyanobacteria and green algae in the soils of Thar Desert (India), J. Arid Environ., 72, 73-83, 2008.

Boison, G., Mergel, A., Jolkver, $\mathrm{H}_{\text {., }}$ and Bothe, $\mathrm{H}_{\text {.: }}$ Bacterial life and dinitrogen fixation at a gypsum rock, Appl. Environ. Microb., 70, 7070-7077, 2004.

Boucher, V. L. and Nash, T. H.: Growth patterns in Ramalina menziesii in California: coastal vs. inland populations, Bryologist, 93, 295-302, 1990.

Breda, N. J. J.: Ground-based measurements of leaf area index: a review of methods, instruments and current controversies, J. Exp. Bot., 54, 2403-2417, doi:10.1093/jxb/erg263, 2003.

Brostoff, W. N., Sharifi, M. R., and Rundel, P. W.: Photosynthesis of cryptobiotic soil crusts in a seasonally inundated system of pans and dunes in the western Mojave Desert, CA: Field studies, Flora, 200, 592-600, 2005.

Brown, P. J. and Dalton, D. A.: In situ physiological monitoring of Lobaria oregana transplants in an old-growth forest canopy, Northwest Science, 76, 230-239, 2002.

Büdel, B.: Ecology and diversity of rock-inhabiting cyanobacteria in tropical regions, Eu. J. Phycol., 34, 361-370, 1999.

Büdel, B., Meyer, A., Salazar, N., Zellner, H., Zotz, G., and Lange, O. L.: Macrolichens of montane rain forests in Panama, Province Chiriqui, Lichenologist, 32, 539-551, 2000.

20 Büdel, B.: Diversity and ecology of biological crusts, in: Progress in Botany, edited by: Lüttge, U. E., Beyschlag, W., Büdel, B., and Francis, D., Springer-Verlag, Berlin - Heidelberg, 386404, 2002.

Büdel, B., Weber, B., Kühl, M., Pfanz, H., Sültemeyer, D., and Wessels, D.: Reshaping of sandstone surfaces by cryptoendolithic cyanobacteria: bioalkalization causes chemical weathering in arid landscapes, Geobiology, 2, 261-268, 2004.

Büdel, B., Bendix, J., Bicker, F. R., and Green, T. G. A.: Dewfall as a water source frequently activates the endolithic cyanobacterial community in the granites of Taylor Valley, Antarctica, J. Phycol., 44, 1415-1424, 2008.

Buermann, W., Wang, Y. J., Dong, J. R., Zhou, L. M., Zeng, X. B., Dickinson, R. E., Potter, C.

30 S., and Myneni, R. B.: Analysis of a multiyear global vegetation leaf area index data set, J. Geophys. Res.-Atmos., 107, 4646, doi:10.1029/2001JD000975, 2002.

Cáceres, M. E. S., Lücking, R., and Rambold, G.: Phorophyte specificity and environmental parameters versus stochasticity as determinants for species composition of corticolous 
crustose lichen communities in the Atlantic rain forest of northeastern Brazil, Mycological Progress, 6, 117-136, 2007.

Caldwell, M. M., Meister, H.-P., Tenhunen, J. D., and Lange, O. L.: Canopy structure, light microclimate and leaf gas exchange of Quercus coccifera L. in a Portuguese macchia: measurements in different canopy layers and simulations with a canopy model, Trees, 1, 25-41, 1986.

Campbell, J. and Coxson, D. S.: Canopy microclimate and arboreal lichen loading in subalpine spruce-fir forest, Can. J. Bot., 79, 537-555, 2001.

Carroll, G. C.: Needle microepiphytes in a Douglas-fir canopy - biomass and distribution patterns, Can. J. Bot.-Revue Canadienne De Botanique, 57, 1000-1007, 1979.

Castellanos, V. A. E., Duran, R., Guzman, S., Briones, O., and Feria, M.: Three-dimensional space utilization of lianas: a methodology, Biotropica, 24, 396-401, 1992.

Chapin, F. S., Woodwell, G. M., Randerson, J. T., Rastetter, E. B., Lovett, G. M., Baldocchi, D. D., Clark, D. A., Harmon, M. E., Schimel, D. S., Valentini, R., Wirth, C., Aber, J. D., Cole,

15 J. J., Goulden, M. L., Harden, J. W., Heimann, M., Howarth, R. W., Matson, P. A., McGuire, A. D., Melillo, J. M., Mooney, H. A., Neff, J. C., Houghton, R. A., Pace, M. L., Ryan, M. G., Running, S. W., Sala, O. E., Schlesinger, W. H., and Schulze, E. D.: Reconciling carbon-cycle concepts, terminology, and methods, Ecosystems, 9, 1041-1050, 2006.

Clark, D. B., Olivas, P. C., Oberbauer, S. F., Clark, D. A., and Ryan, M. G.: First direct landscapescale measurement of tropical rain forest leaf area index, a key driver of global primary productivity, Ecol. Lett., 11, 163-172, 2008.

Clark, D. L., Nadkarni, N. M., and Gholz, H. L.: Growth, net production, litter decomposition, and net nitrogen accumulation by epiphytic bryophytes in a tropical montane forest, Biotropica, 30, 12-23, 1998.

25 Coley, P. D., Kursar, T. A., and Machado, J.-L.: Colonization of tropical rain forest leaves by epiphylls: effects of site and host plant leaf lifetime, Ecology, 74, 619-623, 1993.

Coxson, D. S., Mclntyre, D. D., and Vogel, H. J.: Pulse release of sugars and polyols from canopy bryophytes in tropical montane rain-forest (Guadeloupe, French West-Indies), Biotropica, 24, 121-133, 1992.

30 Currin, C. A. and Pearl, H. W.: Epiphytic nitrogen fixation associated with standing dead shoots of smooth cordgrass, Spartina alterniflora, Estuaries, 21, 108-117, 1998.

DeLuca, T. H., Zackrisson, O., Nilsson, M. C., and Sellstedt, A.: Quantifying nitrogen-fixation in feather moss carpets of boreal forests, Nature, 419, 917-920, 2002.

6991

Devakumar, A. S., Prakash, P. G., Sathik, M. B. M., and Jacob, J.: Drought alters the canopy architecture and micro-climate of Hevea brasiliensis trees, Trees-Struct. Funct., 13, 161-167, 1999.

Dojani, S., Lakatos, M., Rascher, U., Wanek, W., Lüttge, U., and Büdel, B.: Nitrogen input by cyanobacterial biofilms of an inselberg into a tropical rainforest in French Guiana, Flora, 202, 521-529, 2007.

Dufrêne, E. and Bréda, N.: Estimation of deciduous forest leaf area index using direct and indirect methods, Oecologia, 104, 156-162, 1995.

Ellyson, W. J. T. and Sillett, S. C.: Epiphyte communities on Sitka spruce in an old-growth redwood forest, Bryologist, 106, 197-211, 2003.

Evans, R. D. and Johansen, J. R.: Microbiotic crusts and ecosystem processes, Cr. Rev. Plant Sci., 18, 183-225, 1999.

Evans, R. D. and Lange, O. L.: Biological soil crusts and ecosystem nitrogen and carbon dynamics, in: Biological soil crusts: Structure, function, and management, 2nd ed., edited

15 by: Belnap, J. and Lange, O. L., Ecological studies, Springer-Verlag, Berlin, 263-279, 2003.

Eversman, S. and Horton, D.: Recolonization of burned substrates by lichens and mosses in Yellowstone National Park, Northwest Science, 78, 85-92, 2004.

Falge, E., Ryel, R. J., Alsheimer, M., and Tenhunen, J. D.: Effects of stand structure and physiology on forest gas exchange: a simulation study for Norway spruce, Trees-Struct. Funct., 11, 436-448, 1997.

Forman, R. T. T.: Canopy lichens with blue-green algae: a nitrogen source in a Colombian rain forest, Ecology, 56, 1176-1184, 1975.

Forman, R. T. T. and Dowden, D. L.: Nitrogen fixing lichen roles from desert to alpine in the Sangre de Cristo Mountains, New Mexico, Bryologist, 80, 561-570, 1977.

25 Frahm, J.-P.: Die Zunahme von epiphytischen Hängemoosen in Europa am Beispiel einer Lokalität in den Vogesen, Archive for Bryology, 35, 1-10, 2008.

Freiberg, E.: Microclimatic parameters influencing nitrogen fixation in the phyllosphere in a Costa Rican premontane rain forest, Oecologia, 17, 9-18, 1998.

Freiberg, E.: Influence of microclimate on the occurrence of cyanobacteria in the phyllosphere

30 in a premontane rain forest of Costa Rica, Plant Biol., 1, 244-252, 1999.

Freiberg, M. and Freiberg, E.: Epiphyte diversity and biomass in the canopy of lowland and montane forests in Ecuador, J. Trop. Ecology, 16, 673-688, 2000.

Friedmann, E. I.: Endolithic microbial life in hot and cold deserts, Orig. Life Evol. Biosph., 10, 
223-235, 1980.

Friedmann, E. I., Kappen, L., Meyer, M. A., and Nienow, J. A.: Long-term productivity in the cryptoendolithic microbial community of the Ross Desert, Antarctica, Microbial Ecol., 25, 51-69, 1993.

5 Fürnkranz, M., Wanek, W., Richter, A., Abell, G., Rasche, F., and Sessitsch, A.: Nitrogen fixation by phyllosphere bacteria associated with higher plants and their colonizing epiphytes of a tropical lowland rainforest of Costa Rica, The ISME Journal, 2, 561-570, 2008.

Galloway, J. N.: The global nitrogen cycle, in: Biogeochemistry, edited by: Schlesinger, W. H., Treatise on Geochemistry, Elsevier-Pergamon, Oxford, 557-583, 2005.

10 Garcia-Pichel, F. and Belnap, J.: Microenvironments and microscale productivity of cyanobacterial desert crusts, J. Phycol., 32, 77-782, 1996.

Garcia-Pichel, F., Belnap, J., Neuer, S., and Schanz, F.: Estimates of global cyanobacterial biomass and its distribution, in: Algological Studies, edited by: Chapman, R., Hoffmann, L., Komárková, J., Krienitz, L., and Kristiansen, J., E. Schweizerbart'sche Verlagsbuchhandlung, 15 Stuttgart, 213-227, 2003.

Gaydarova, P. N.: Deciduous forest communities in the Black Sea coastal Strandzha region: temporal and spatial characteristics of leaf area index and density, Trees-Struct. Funct., 17, 237-243, 2003.

Gerwing, J. J. and Farias, D. L.: Integrating liana abundance and forest stature into an estimate of total aboveground biomass for an eastern Amazonian forest, J. Trop. Ecology, 16, 327$335,2000$.

Gerwing, J. J. and Vidal, E.: Changes in liana abundance and species diversity eight years after liana cutting and logging in an eastern Amazonian forest, Conserv. Biol., 16, 544-548, 2002.

25 Goldewijk, K. K.: Estimating global land use change over the past 300 years: The HYDE Database, Global Biogeochem. Cy., 15, 417-433, 2001.

Gratani, L. and Varone, L.: Plant crown traits and carbon sequestration capability by Platanus hybrida Brot. in Rome, Landscape Urban Plan., 81, 282-286, 2007.

Hanson, R. B.: Nitrogen fixation (acetylene reduction) in a salt marsh amended with sewage sludge and organic carbon and nitrogen compounds, Appl. Environ. Microb., 33, 846-852, 1977.

Hoppert, M., Flies, C., Pohl, W., Gunzl, B., and Schneider, J.: Colonization strategies of lithobiontic microorganisms on carbonate rocks, Environ. Geol., 46, 421-428, 2004.

6993

Horne, A. J.: The ecology of nitrogen fixation on Signy Island South Orkney Islands, Br. Antarct. Surv. Bull., 27, 1-18, 1972.

Housman, D. C., Powers, H. H., Collins, A. D., and Belnap, J.: Carbon and nitrogen fixation differ between successional stages of biological soil crusts in the Colorado Plateau and Chihuahuan Desert, J. Arid Environ., 66, 620-634, 2006.

Isichei, A. O.: Nitrogen fixation by blue-green algal soil crusts in Nigerian savanna, in: Nitrogen cycling in West Africa ecosystems, edited by: Rosswall, T., Royal Swedish Academy of Sciences, Stockholm, 191-198, 1980.

Jeffries, D. L., Link, S. O., and Klopatek, J. M.: $\mathrm{CO}_{2}$ fluxes of cryptogamic crusts I. Response

10 to resaturation, New Phytol., 125, 163-173, 1993.

Jones, K.: Nitrogen fixation in phyllosphere of Douglas-fir, Pseudotsuga-Douglasii, Ann. Bot.London, 34, 239-244, 1970.

Juhász, A., Balogh, J., Csintalan, Z., and Tuba, Z.: Carbon sequestration of the poikilohydric moss carpet vegetation in semidesert sandy grassland ecosystem, Acta Biologica Szegediensis, 46, 223-225, 2002.

Kappen, L., Lange, O. L., Schulze, E.-D., Buschbom, U., and Evenari, M.: Ecophysiological investigations on lichens of the Negev Desert. VII. The influence of the habitat exposure on dew imbibition and photosynthetic productivity., Flora, 169, 216-229, 1980.

Kappen, L., Schroeter, B., Green, T. G. A., and Seppelt, R. D.: Chlorophyll a fluorescence and $\mathrm{CO}_{2}$ exchange of Umbilicaria aprina under extreme light stress in the cold, Oecologia, 113, 325-331, 1998.

Kazda, M. and Salzer, J.: Leaves of lianas and self-supporting plants differ in mass per unit area and in nitrogen content, Plant Biol., 2, 268-271, 2000.

Klopatek, J. M.: The use of cryptogamic crusts as indicators of disturbance in semiarid land-

25 scapes, in: Ecological indicators, edited by: Kenzie, D. H. M., Hyatt, D. E., and MacDonald, V. J., Elsevier, London, 773-786, 1992.

Kucharik, C. J., Foley, J. A., Delire, C., Fisher, V. A., Coe, M. T., Lenters, J. D., Young-Molling, C., Ramankutty, N., Norman, J. M., and Gower, S. T.: Testing the performance of a Dynamic Global Ecosystem Model: Water balance, carbon balance, and vegetation structure, Global Biogeochem. Cy., 14, 795-825, 2000.

Kurina, L. M. and Vitousek, P. M.: Controls over the accumulation and decline of a nitrogenfixing lichen, Stereocaulon vulcani, on young Hawaiian lava flows, J. Ecol., 87, 784-799, 1999. 
Lakatos, M., Rascher, U., and Büdel, B.: Functional characteristics of corticolous lichens in the understory of a tropical lowland rain forest, New Phytol., 172, 679-695, 2006.

Lange, O. L., Schulze, E.-D., and Koch, W.: Experimentell-ökologische Untersuchungen an Flechten der Negev-Wüste. III. $\mathrm{CO}_{2}$-Gaswechsel und Wasserhaushalt von Krusten- und Blat-

5 tflechten am natürlichen Standort während der sommerlichen Trockenperiode, Flora, 159, 525-528, 1970.

Lange, O. L., Kidron, G. J., Büdel, B., Meyer, A., Kilian, E., and Abeliovich, A.: Taxonomic composition and photosynthetic characteristics of the 'biological soil crusts' covering sand dunes in the wester Negev Desert, Funct. Ecol., 6, 519-527, 1992.

10 Lange, O. L., Büdel, B., Meyer, A., and Kilian, E.: Further evidence that activation of net photosynthesis by dry cyanobacterial lichens requires liquid water, Lichenologist, 25, 175189, 1993.

Lange, O. L., Büdel, B., Zellner, H., Zotz, G., and Meyer, A.: Field measurements of water relations and $\mathrm{CO}_{2}$ exchange of the tropical, cyanobacterial basidiolichen Dictyonema glabratum

15 in a Panamanian rainforest, Botanica Acta, 107, 279-290, 1994a.

Lange, O. L., Meyer, A., Zellner, H., and Heber, U.: Photosynthesis and water relations of lichen soil crusts: field measurements in the coastal fog zone of the Namib Desert, Funct. Ecol., 8 , 253-264, 1994b.

Lange, O. L., Belnap, J., Reichenberger, H., and Meyer, A.: Photosynthesis of green algal

20 soil crust lichens from arid lands in southern Utah, USA: Role of water content on light and temperature responses of $\mathrm{CO}_{2}$ exchange, Flora, 192, 1-15, 1997.

Lange, O. L., Belnap, J., and Reichenberger, H.: Photosynthesis of the cyanobacterial soilcrust lichen Collema tenax from arid lands in southern Utah, USA: Role of water content on light and temperature responses of $\mathrm{CO}_{2}$ exchange, Funct. Ecol., 12, 195-202, 1998a.

25 Lange, O. L., Hahn, S. C., Meyer, A. and Tenhunen, J. D.: Upland tundra in the foothills of the Brooks Range, Alaska, USA: lichen long-term photosynthetic $\mathrm{CO}_{2}$ uptake and net carbon gain, Arctic Alpine Res., 30, 252-261, 1998b.

Lange, O. L.: Die Lebensbedingungen von Bodenkrusten-Organismen: Tagesverlauf der Photosynthese einheimischer Erdflechten, Hoppea, 61, 423-443, 2000a.

30 Lange, O. L.: Photosynthetic performance of a gelatinous lichen under temperate habitat conditions: long-term monitoring of $\mathrm{CO}_{2}$ exchange of Collema cristatum, Bibliotheca Lichenologica, 75, 307-332, 2000b.

Lange, O. L., Büdel, B., Meyer, A., Zellner, H., and Zotz, G.: Lichen carbon gain under trop-

6995

ical conditions: water relations and $\mathrm{CO}_{2}$ exchange of three Leptogium species of a lower montane rainforest in Panama, Flora, 195, 172-190, 2000.

Lange, O. L.: Photosynthetic productivity of the epilithic lichen Lecanora muralis: long-term field monitoring of $\mathrm{CO}_{2}$ exchange and its physiological interpretation - III. Diel, seasonal, and annual carbon budgets, Flora, 198, 277-292, 2003.

Lange, O. L., Büdel, B., Meyer, A., Zellner, H., and Zotz, G.: Lichen carbon gain under tropical conditions: water relations and $\mathrm{CO}_{2}$ exchange of Lobariaceae species of a lower montane rainforest in Panama, Lichenologist, 36, 329-342, 2004.

Lange, O. L. and Green, T. G. A.: Photosynthetic performance of the squamulose soil-crust

10 lichen Squamarina lentigera: laboratory measurements and long-term monitoring of $\mathrm{CO}_{2}$ exchange in the fiel, Bibliotheca Lichenologica, 88, 363-360, 2004.

Lange, O. L., Green, T. G. A., Melzer, B., Meyer, A., and Zellner, $\mathrm{H} .:$ Water relations and $\mathrm{CO}_{2}$ exchange of the terrestrial lichen Teloschistes capensis in the Namib fog desert: Measurements during two seasons in the field and under controlled conditions, Flora, 201, 268-280, 2006.

Last, F. T. and Deighton, F. C.: Non-parasitic microflora on surfaces of living leaves, British Mycological Society Transactions, 48, 83-99, 1965.

Lawrence, P. J. and Chase, T. N.: Representing a new MODIS consistent land surface in the Community Land Model (CLM 3.0), J. Geophys. Res.-Biogeosciences, 112, G01023, doi:10.1029/2006JG000168, 2007.

Lücking, R. and Matzer, M.: High foliicolous lichen alpha-diversity on individual leaves in Costa Rica and Amazonian Ecuador, Biodivers. Conserv., 10, 2139-2152, 2001.

Lüttge, U., Büdel, B., Ball, E., Strube, F., and Weber, P.: Photosynthesis of terrestrial cyanobacteria under light and desiccation stress as expressed by chlorophyll fluorescence and gas exchange, J. Exp. Bot., 46, 309-319, 1995.

Matthes-Sears, U., Gerrath, J. A., and Larson, D. W.: Abundance, biomass, and productivity of endolithic and epilithic lower plants on the temperate-zone cliffs of the Niagara Escarpment, Canada, Int. J. Plant Sci., 158, 451-460, 1997.

Matthews, E.: Global vegetation and land use: new high-resolution data bases for climate studies, J. Clim. Appl. Meteorol., 22, 474-487, 1983.

Mayland, H. F. and Mclntosh, T. H.: Availability of biologically fixed atmospheric nitrogen-15 to higher plants, Nature, 209, 421-422, 1966.

Mayland, H. F., McIntosh, T. H., and Fuller, W. H.: Fixation of isotopic nitrogen on a semiarid soil 
by algal crust organisms, Soil Science Society of America Proceedings, 30, 56-60, 1966.

McCune, B.: Gradients in epiphyte biomass in three Pseudotsuga-Tsuga forests of different ages in Western Oregon and Washington, Bryologist, 96, 405-411, 1993.

McCune, B.: Using epiphyte litter to estimate epiphyte biomass, Bryologist, 97, 396-401, 1994.

5 McCune, B., Amsberry, K. A., Camacho, F. J., Clery, S., Cole, C., Emerson, C., Felder, G., French, P., Greene, D., Harris, B., Hutten, M., Larson, B., Lesko, M., Maiors, S., Markwell, T., Parker, G. G., Pendergrass, K., E. B. Peterson, Peterson, E. T., Platt, J., Proctor, J., Rambo, T., Rosso, A., Shaw, D., Turner, R., and Widmer, M.: Vertical profile of epiphytes in a Pacific northwest old-growth forest, Northwest Science, 71, 145-152, 1997.

10 Pankratova, E. M.: Functioning of cyanobacteria in soil ecosystems, Eurasian Soil Science, 39, S118-S127, 2006.

Peveling, E., Burg, H., and Tenberge, K. B.: Epiphytic algae and fungi on spruce needles, Symbiosis, 12, 173-187, 1992.

Philips, S. and Belnap, J.: Shifting carbon dynamics due to the effect of Bromus tectorum invasion on biological soil crust, Bull ESA, 205, 1998 Meeting Abstracts, 1998.

Pike, L. H., Rydell, R. A., and Denison, W. C.: A 400-year-old Douglas fir tree and its epiphytes: biomass, surface area, and their distributions, Can. J. Forest Res., 7, 680-699, 1977.

Pike, L. H.: The importance of epiphytic lichens in mineral cycling, Bryologist, 81, 247-257, 1978.

20 Prentice, C., Farquhar, G. D., Fasham, M. J. R., Goulden, M., Heimann, M., Jaramillo, V. J., Kheshgi, H. S., LeQuere, C., Scholes, R. J., and Wallace, D. W. R.: The carbon cycle and atmospheric carbon dioxide. The scientific basis (Contribution of Working Group 1 to the Third Assessment Report of the Intergovernmental Panel on Climate Change), in: Climate Change 2001, edited by: Houghton, J., Ding, Y., Griggs, D. J., Noguer, M., Linden, P. J. v. d.,

25 Dai, X., Maskell, K., and Johnson, C. A., Cambridge University Press, Cambridge, 183-237, 2001.

Prigent, C., Aires, F., Rossow, W., and Matthews, E.: Joint characterization of vegetation by satellite observations from visible to microwave wavelengths: A sensitivity analysis, J. Geophys. Res.-Atmos., 106, 20665-20685, 2001.

30 Putz, F. E.: Liana biomass and leaf area of a "Tierra Firme" forest in the Rio Negro Basin, Venezuela, Biotropica, 15, 185-189, 1983.

Radies, D. N. and Coxson, D. S.: Macrolichen colonization on 120-140 year old Tsuga heterophylla in wet temperate rainforests of central-interior British Columbia: a comparison of

6997

lichen response to even-aged versus old-growth stand structures, Lichenologist, 36, 235247, 2004.

Ramankutty, N. and Foley, J. A.: Estimating historical changes in global land cover: Croplands from 1700 to 1992, Global Biogeochem. Cy., 13, 997-1027, 1999.

5 Rascher, U., Lakatos, M., Büdel, B., and Lüttge, U.: Photosynthetic field capacity of cyanobacteria of a tropical inselberg of the Guiana Highlands, Eur. J. Phycol., 38, 247-256, 2003.

Reich, P. B., Hobbie, S. E., Lee, T., Ellsworth, D. S., West, J. B., Tilman, D., Knops, J. M. H., Naeem, S., and Trost, J.: Nitrogen limitation constrains sustainability of ecosystem response to $\mathrm{CO}_{2}$, Nature, 440, 922-925, 2006.

10 Rhoades, F. M.: Biomass of epiphytic lichens and bryophytes on Abies lasiocarpa on a Mt." Baker lava flow, Washington, Bryologist, 84, 39-47, 1981.

Roskoski, J. P.: Epiphyll dynamics of a tropical understory, Oikos, 37, 252-256, 1981.

Rossi, F., Facini, O., Rotondi, A., Loreti, S., and Georgiadis, T.: Optical properties of juniper and lentisk canopies in a coastal Mediterranean macchia shrubland, Trees-Struct. Funct., 15, 462-471, 2001.

Ruinen, J.: Occurrence of Beijerinckia species in the phyllosphere, Nature, 177, 220-221, 1956.

Running, S. W., Nemani, R. R., Heinsch, F. A., Zhao, M. S., Reeves, M., and Hashimoto, H.: A continuous satellite-derived measure of global terrestrial primary production, Bioscience, 54, 547-560, 2004.

Sala, A., Sabate, S., Gracia, C., and Tenhunen, J. D.: Canopy structure within a Quercus Ilex forested watershed - variations due to location, phenological development, and water availability, Trees-Struct. Funct., 8, 254-261, 1994.

San José, J. J. and Bravo, C. R.: $\mathrm{CO}_{2}$ exchange in soil algal crusts occurring in the Trachypogon savannas of the Orinoco Llanos, Venezuela, Plant Soil, 135, 233-244, 1991.

Sánchez-Azofeifa, G. A., Kalácska, M., Espírito-Santo, M. M. D., Fernandes, G. W., and Schnitzer, S.: Tropical dry forest succession and the contribution of lianas to wood area index (WAl), Forest Ecol. Manage., in press, 2009.

Schlesinger, W. H., Pippen, J. S., Wallenstein, M. D., Hofmockel, K. S., Klepeis, D. M., and

30 Mahall, B. E.: Community composition and photosynthesis by photoautotrophs under quartz pebbles, southern Mojave Desert, Ecology, 84, 3222-3231, 2003.

Schmidt, S. K., Reed, S. C., Nemergut, D. R., Grandy, A. S., Cleveland, C. C., Weintraub, M. N., Hill, A. W., Costello, E. K., Meyer, A. F., Neff, J. C., and Martin, A. M.: The earliest stages of 
ecosystem succession in high-elevation (5000 metres above sea level), recently deglaciated soils, Proceedings of the Royal Society B-Biological Sciences, 275, 2793-2802, 2008.

Scurlock, J. M. O., Asner, G. P., and Gower, S. T.: Global leaf area index data from field measurements, 1932-2000. Data set, online available at: http://www.daac.ornl.gov from the

5 Oak Ridge National Laboratory Distributed Active Archive Center, Oak Ridge, Tennessee, USA, 2001.

Sheridan, R. P.: Epicaulous, nitrogen-fixing microepiphytes in a tropical mangal community, Guadeloupe, French West-Indies, Biotropica, 23, 530-541, 1991a.

Sheridan, R. P.: Nitrogenase activity by Hapalosiphon flexuosus associated with Sphagnum erythrocalyx mats in the cloud forest on the volcano La Soufriere, Guadeloupe, French West Indies, Biotropica, 23, 134-140, 1991b.

Sherwood, M. and Carroll, G.: Fungal succession on needles and young twigs of old-growth Douglas fir, Mycologia, 66, 499-506, 1974.

Sillett, S. C.: Branch epiphyte assemblages in the forest interior and on the clearcut edge of a 700-year-old Douglas fir canopy in Western Oregon, Bryologist, 98, 301-312, 1995.

Sillett, S. C. and Rambo, T. R.: Vertical distribution of dominant epiphytes in Douglas-fir forests of the central Oregon Cascades, Northwest Science, 74, 44-49, 2000.

Skarpe, C. and Henriksson, E.: Nitrogen fixation by cyanobacterial crusts and by associativesymbiotic bacteria in western Kalahari, Botswana, Arid Soil Res. Rehabil., 1, 55-59, 1987.

20 Søchting, U.: Epiphyllic cover on spruce needles in Denmark, Ann. Bot. Fennici, 34, 157-164, 1997.

Solhaug, K. A., Gauslaa, Y., and Haugen, J.: Adverse effects of epiphytic crustose lichens upon stem photosynthesis and chlorophyll of Populus tremula L, Botanica Acta, 108, 233239, 1995.

25 Thiet, R. K., Boerner, R. E. J., Nagy, M., and Jardine, R.: The effect of biological soil crusts on throughput of rainwater and N into Lake Michigan sand dune soils, Plant Soil, 278, 235-251, 2009.

Tretiach, M.: Ecophysiology of calcicolous lichens: progress and problems, Giornale Botanico Italiano, 129, 159-184, 1995.

30 Tretiach, M. and Geletti, A.: $\mathrm{CO}_{2}$ exchange of the endolithic lichen Verrucaria baldensis from Karst habitats in northern Italy, Oecologia, 111, 515-522, 1997.

Turetsky, M. R.: The role of bryophytes in carbon and nitrogen cycling, Bryologist, 106, 395409, 2003.

6999

Veluci, R. M., Neher, D. A., and Weicht, T. R.: Nitrogen fixation and leaching of biological soil crust communities in mesic temperate soils, Microbial Ecol., 51, 189-196, 2006.

Vincke, C., Granier, A., Breda, N., and Devillez, F.: Evapotranspiration of a declining Quercus robur (L.) stand from 1999 to 2001 . II. Daily actual evapotranspiration and soil water reserve, Ann. For. Sci., 62, 615-623, 2005.

Walker, J. J., Spear, J. R., and Pace, N. R.: Geobiology of a microbial endolithic community in the Yellowstone geothermal environment, Nature, 434, 1011-1014, 2005.

Wanek, W., and Portl, K.: Phyllosphere nitrogen relations: reciprocal transfer of nitrogen between epiphyllous liverworts and host plants in the understorey of a lowland tropical wet

10 forest in Costa Rica, New Phytol., 166, 577-588, 2005.

Watson, R. T., Noble, I. R., Bolin, B., Ravindranath, N. H., Verardo, D. J., and Dokken, D. J.: Land use, land-use change and forestry, in: IPCC Special Reports on Climate Change, edited by: Watson, R. T., Noble, I. R., Bolin, B., Ravindranath, N. H., Verardo, D. J., and Dokken, D. J., Cambridge University Press, Cambridge, 377 pp., 2000.

15 Weaver, P. L., Medina, E., Pool, D., Dugger, K., Gonzales-Liboy, J., and Cuevas, E.: Ecological observations in the dwarf cloud forest of the Luquillo Mountains in Puerto Rico, Biotropica, 18, 79-85, 1986.

Weaver, P. L. and Murphy, P. G.: Forest structure and productivity in Puerto Rico's Luquillo Mountains, Biotropica, 22, 69-82, 1990.

20 Weber, B.: Biologie und Ökologie gesteinsbewohnender Blaualgen/Cyanobakterien in der Dornbuschsavanne Nord-Transvaals, Südafrika, University of Würzburg, Germany, 1994.

Weber, B., Scherr, C., Reichenberger, H., and Büdel, B.: Fast reactivation by high air humidity and photosynthetic performance of alpine lichens growing endolithically in limestone, Arctic, Antarct. Alp. Res., 39, 309-317, 2007.

25 Weber, B., Olehowski, C., Knerr, T., Hill, J., Deutschewitz, K., Wessels, D. C. J., Eitel, B., and Büdel, B.: A new approach for mapping of biological soil crusts in semidesert areas with hyperspectral imagery, Remote Sens. Environ., 112, 2187-2201, 2008.

Weiskittel, A. R. and Maguire, D. A.: Branch surface area and its vertical distribution in coastal Douglas-fir, Trees-Struct. Funct., 20, 657-667, 2006.

30 Wessels, D. C. A. and Kappen, L.: Photosynthetic performance of rock-colonising lichens in the Mount Zebra National Park, South Africa, Koedoe, 36, 27-48, 1993.

Whitman, W. B., Coleman, D. C., and Wiebe, W. J.: Prokaryotes: The unseen majority, Proceedings of the National Academy of Sciences of the United States of America, 95, 6578- 
6583, 1998.

Whittaker, R. H. and Likens, G. E.: Primary production: Biosphere and man, Hum. Ecol., 1, 357-369, 1973.

Wilske, B., Burgheimer, J., Karnieli, A., Zaady, E., Andreae, M. O., Yakir, D., and Kesselmeier,

5 J.: The $\mathrm{CO}_{2}$ exchange of biological soil crusts in a semiarid grass-shrubland at the northern transition zone of the Negev desert, Israel, Biogeosciences, 5, 1411-1423, 2008, http://www.biogeosciences.net/5/1411/2008/.

Wiman, B. L. B. and Gaydarova, P. N.: Spectral composition of shade light in coastal-zone oak forests in SE Bulgaria, and relationships with leaf area index: a first overview, Trees-Struct. Funct., 22, 63-76, 2008.

Winkler, J. B. and Kappen, L.: Photosynthetic capacity of endolithic lichens from South-Africa, Bibliotheca Lichenologica, 67, 165-181, 1997.

Yeager, C. M., Kornosky, J. L., Morgan, R. E., Cain, E. C., Garcia-Pichel, F., Housman, D. C., Belnap, J., and Kuske, C. R.: Three distinct clades of cultured heterocystous cyanobacteria constitute the dominant $\mathrm{N}_{2}$-fixing members of biological soil crusts of the Colorado Plateau, USA, FEMS Microbiol.y Ecol., 60, 85-97, 2007.

Yoneda, T.: Surface area of woody organs of an evergreen broadleaf forest tree in Japan and Southeast Asia, J. Plant Res., 106, 229-237, 1993.

Zaady, E., Kuhn, U., Wilske, B., Sandoval-Soto, L., and Kesselmeier, J.: Patterns of $\mathrm{CO}_{2}$ exchange in biological soil crusts of successional age, Soil Biol. Biochem., 32, 959-966, 2000.

Zotz, G., Büdel, B., Meyer, A., Zellner, H., and Lange, O. L.: In situ studies of water relations and $\mathrm{CO}_{2}$ exchange of the tropical macrolichen, Sticta tomentosa, New Phytol., 139, 525535, 1998.

Zotz, G.: Altitudinal changes in diversity and abundance of non-vascular epiphytes in the Tropics - an ecophysiological explanation, Selbyana, 20, 256-260, 1999.

Table A1. Annual net carbon uptake fluxes (photosynthesis minus respiration) of biological soil crusts (BSC) in arid and semiarid regions, (b) BSC in other sparsely vegetated regions, and (c) biological crusts on rocks (BRC).

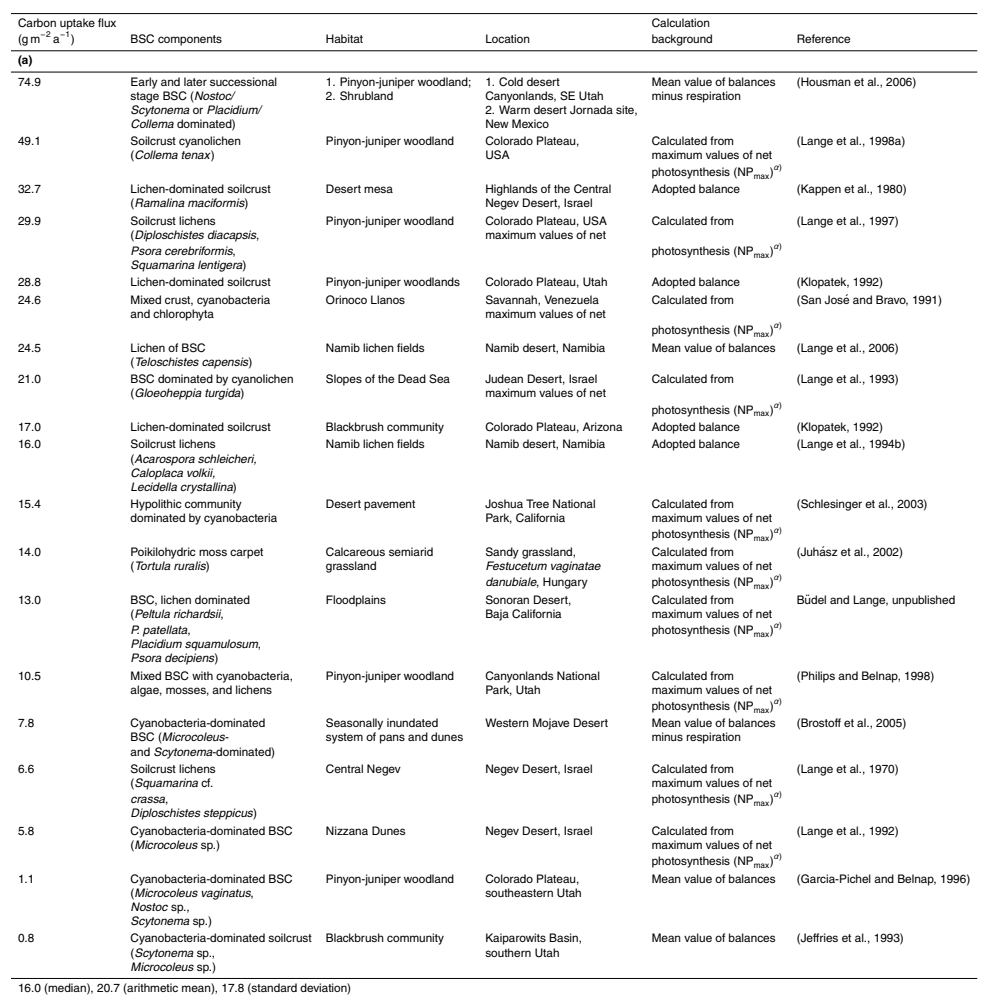


Table A1. Continued.

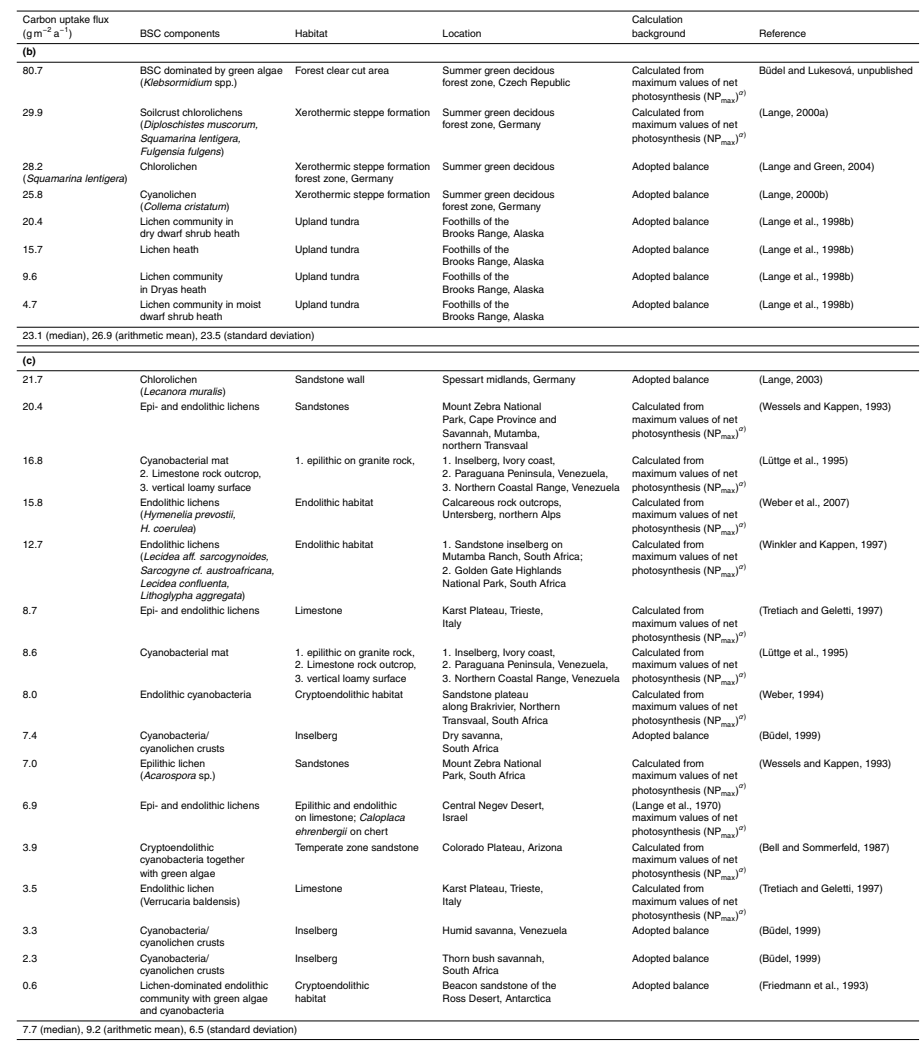

${ }^{\alpha)} \mathrm{NP}_{\max }$ values were scaled to estimated average ambient conditions.

7003

Table A2. Global surface area of terrestrial arid and semiarid regions (dry-lands).

\begin{tabular}{ll}
\hline Area $\left(10^{13} \mathrm{~m}^{2}\right)$ & References \\
\hline 7.8 & (Watson et al., 2000) \\
6.8 & (Asner et al., 2003) \\
6.6 & (Ramankutty and Foley, 1999) \\
6.5 & (Whittaker and Likens, 1973) \\
6.4 & (Garcia-Pichel et al., 2003) \\
6.0 & (Kucharik et al., 2000) \\
5.5 & (Goldewijk, 2001) \\
5.0 & (Lawrence al., 1979) \\
5.0 & (and Chase, 2007) \\
\hline 6.4 (median), 6.2 (arithmetic mean), 0.9 (standard deviation) \\
\hline
\end{tabular}


Table A3. Annual net carbon uptake flux (photosynthesis minus respiration) of epiphytic and epiphyllic crusts (EPC).

\begin{tabular}{|c|c|c|c|c|c|}
\hline $\begin{array}{l}\text { Carbon uptake flux } \\
\left(\mathrm{g} \mathrm{m}^{-2} \mathrm{a}^{-1}\right)\end{array}$ & $\begin{array}{l}\text { EPC } \\
\text { components }\end{array}$ & Habitat & Location & $\begin{array}{l}\text { Calculation } \\
\text { background }\end{array}$ & Reference \\
\hline 167.7 & $\begin{array}{l}\text { Homoiomerous cyanolichen } \\
\text { (Leptogium cyanescens) }\end{array}$ & Lower montane rainforest & $\begin{array}{l}\text { Cordillera Central, } \\
\text { Republic of Panama }\end{array}$ & Adopted balance & (Lange et al., 2000) \\
\hline 116.3 & $\begin{array}{l}\text { Homoiomerous cyanolichen } \\
\text { (Leptogium phyllocarpum) }\end{array}$ & Lower montane rainforest & $\begin{array}{l}\text { Cordillera Central, } \\
\text { Republic of Panama }\end{array}$ & Adopted balance & (Lange et al., 2000) \\
\hline 86.0 & $\begin{array}{l}\text { Epiphytic Lobariaceae } \\
\text { (Sticta weigelii) }\end{array}$ & Lower montane rainforest & $\begin{array}{l}\text { Cordillera Central, } \\
\text { Republic of Panama }\end{array}$ & Adopted balance & (Lange et al., 2004) \\
\hline 78.9 & $\begin{array}{l}\text { Cyanobacterial basidiolichen } \\
\text { (Dictyonema glabratum) }\end{array}$ & Lower montane rainforest & $\begin{array}{l}\text { Cordillera Central, } \\
\text { Republic of Panama }\end{array}$ & Adopted balance & (Lange et al., 1994a) \\
\hline 74.2 & $\begin{array}{l}\text { Epiphytic Lobariaceae } \\
\text { (Sticta sublimbata) }\end{array}$ & Lower montane rainforest & $\begin{array}{l}\text { Cordillera Central, } \\
\text { Republic of Panama }\end{array}$ & Adopted balance & (Lange et al., 2004) \\
\hline 60.2 & $\begin{array}{l}\text { Epiphytic Lobariaceae } \\
\text { (Sticta tomentosa) }\end{array}$ & Lower montane rainforest & $\begin{array}{l}\text { Cordillera Central, } \\
\text { Republic of Panama }\end{array}$ & Adopted balance & (Zotz et al., 1998) \\
\hline 29.5 & $\begin{array}{l}\text { Epiphytic Lobariaceae } \\
\text { (Pseudocyphellaria intricata) }\end{array}$ & Lower montane rainforest & $\begin{array}{l}\text { Cordillera Central, } \\
\text { Republic of Panama }\end{array}$ & Adopted balance & (Lange et al., 2004) \\
\hline 26.8 & $\begin{array}{l}\text { Homoiomerous cyanolichen } \\
\text { (Leptogium azureum) }\end{array}$ & Lower montane rainforest & $\begin{array}{l}\text { Cordillera Central, } \\
\text { Republic of Panama }\end{array}$ & Adopted balance & (Lange et al., 2000) \\
\hline 25.4 & $\begin{array}{l}\text { Epiphytic Lobariaceae } \\
\text { (Pseudocyphellaria aurata) }\end{array}$ & Lower montane rainforest & $\begin{array}{l}\text { Cordillera Central, } \\
\text { Republic of Panama }\end{array}$ & Adopted balance & (Lange et al., 2004) \\
\hline 9.3 & $\begin{array}{l}\text { Corticolous lichen } \\
\text { (Coenogonium linkii) }\end{array}$ & $\begin{array}{l}\text { Tropical evergreen } \\
\text { lowland rainforest }\end{array}$ & $\begin{array}{l}\text { Les Nouragues National } \\
\text { Park, French Guiana }\end{array}$ & $\begin{array}{l}\text { Calculated from } \\
\text { maximum values of net } \\
\text { photosynthesis }\left(\mathrm{NP}_{\max }\right)^{\alpha)}\end{array}$ & (Lakatos et al., 2006) \\
\hline 5.6 & $\begin{array}{l}\text { Epiphytic Lobariaceae } \\
\text { (Lobaria crenulata) }\end{array}$ & Lower montane rainforest & $\begin{array}{l}\text { Cordillera Central, } \\
\text { Republic of Panama }\end{array}$ & $\begin{array}{l}\text { Calculated from } \\
\text { maximum values of net } \\
\text { photosynthesis }\left(\mathrm{NP}_{\max }\right)^{\alpha)}\end{array}$ & (Lange et al., 2004) \\
\hline 2.7 & $\begin{array}{l}\text { Corticolous lichen } \\
\text { (Cryptothecia rubrocincta) }\end{array}$ & $\begin{array}{l}\text { Tropical evergreen } \\
\text { lowland rainforest }\end{array}$ & $\begin{array}{l}\text { Les Nouragues National } \\
\text { Park, French Guiana }\end{array}$ & $\begin{array}{l}\text { Calculated from } \\
\text { maximum values of net } \\
\text { photosynthesis }\left(\mathrm{NP}_{\text {max }}\right)^{\alpha)}\end{array}$ & (Lakatos et al., 2006) \\
\hline 1.9 & $\begin{array}{l}\text { Corticolous lichen } \\
\text { (Thelotrema alboolivaceum) }\end{array}$ & $\begin{array}{l}\text { Tropical evergreen } \\
\text { lowland rainforest }\end{array}$ & $\begin{array}{l}\text { Les Nouragues National } \\
\text { Park, French Guiana }\end{array}$ & $\begin{array}{l}\text { Calculated from } \\
\text { maximum values of net } \\
\text { photosynthesis }\left(\mathrm{NP}_{\max }\right)^{\alpha)}\end{array}$ & (Lakatos et al., 2006) \\
\hline 1.1 & $\begin{array}{l}\text { Corticolous lichen } \\
\text { (Phyllopsora corallina) }\end{array}$ & $\begin{array}{l}\text { Tropical evergreen } \\
\text { lowland rainforest }\end{array}$ & $\begin{array}{l}\text { Les Nouragues National } \\
\text { Park, French Guiana }\end{array}$ & $\begin{array}{l}\text { Calculated from } \\
\text { maximum values of net } \\
\text { photosynthesis }\left(\mathrm{NP}_{\max }\right)^{\alpha)}\end{array}$ & (Lakatos et al., 2006) \\
\hline$(37-64)$ & $\begin{array}{l}\text { Epiphytic bryophytes } \\
\text { lower montane wet forest }\end{array}$ & Tropical & Costa Rica & Adopted balance & (Clark et al., 1998) \\
\hline
\end{tabular}

${ }^{\alpha)} \mathrm{NP}_{\max }$ values were scaled to estimated average ambient conditions.

Table A4. Global tropical forest area.

\begin{tabular}{ll}
\hline Forest area $\left(10^{13} \mathrm{~m}^{2}\right)$ & References \\
\hline 1.9 & (Kucharik et al., 2000) \\
1.8 & (Watson et al., 2000) \\
1.7 & (Matthews, 1983) \\
1.7 & (Whittaker and Likens, 1973) \\
1.7 & (Ramankutty and Foley, 1999) \\
1.6 & (Prigent et al., 2001) \\
1.5 & (Matthews, 1983) \\
1.5 & (Ajtay et al., 1979) \\
1.4 & (Lawrence and Chase, 2007) \\
1.3 & (Matthews, 1983) \\
\hline 1.7 (median), 1.6 (arithmetic mean), 0.2 (standard deviation)
\end{tabular}


Table A5. Plant surface area of (a) leaves of tropical evergreen trees (leaf area index, LAI), (b) tropical lianas (LAI), (c) leaves of evergreen trees and shrubs (LAl; temperate and boreal), and (d) stems and branches of trees and shrubs (wood area index, WAI; stem area index, SAl).

\begin{tabular}{|c|c|c|c|}
\hline Area index $\left(\mathrm{m}^{2} \mathrm{~m}^{-2}\right)$ & Forest type & Location & References \\
\hline \multicolumn{4}{|l|}{ (a) } \\
\hline 12.3 & Tropical lowland rainforest & Thailand & (Arora and Boer, 2005) \\
\hline 8.0 & Tropical rainforest & Global average & (Whittaker and Likens, 1973) \\
\hline 7.4 & Evergreen tropical forest & Thailand & (Putz, 1983) \\
\hline 7.3 & Subtropical wet forest & Puerto Rico & (Weaver et al., 1986) \\
\hline 7.3 & Tropical lowland rainforest & Malaysia & (Putz, 1983) \\
\hline 6.0 (up to 13 ) & Tropical upland wet forest & Costa Rica & (Clark et al., 2008) \\
\hline 5.5 & Rubber tree forest & Maharastra, India & (Devakumar et al., 1999) \\
\hline 5.2 & Tropical rainforest & Rio Negro Basin, Venezuela & (Putz, 1983) \\
\hline 5.0 & Lower montane rainforest & Puerto Rico & (Weaver and Murphy, 1990) \\
\hline 4.8 & Tropical evergreen broadleaf forest & Global average & (Scurlock et al., 2001) \\
\hline 4.7 & Tropical deciduous forest & Mexico & (Arora and Boer, 2005) \\
\hline 4.0 & Broadleaf forests & Amazon & (Buermann et al., 2002) \\
\hline 3.3 & Lower montane rainforest & Puerto Rico & (Weaver and Murphy, 1990) \\
\hline 2.0 & Lower montane rainforest & Puerto Rico & (Weaver et al., 1986) \\
\hline$(5-8)$ & Tropical forest & Amazon & (Arora and Boer, 2005) \\
\hline (6-7) & Subtropical wet forest & Puerto Rico & (Weaver and Murphy, 1990) \\
\hline (3-5) & Lower montane rainforest & Puerto Rico & (Weaver and Murphy, 1990) \\
\hline (3-3.5) & Lower montane rainforest & Puerto Rico & (Weaver and Murphy, 1990) \\
\hline
\end{tabular}

Table A5. Continued.

\begin{tabular}{|c|c|c|c|}
\hline Area index $\left(\mathrm{m}^{2} \mathrm{~m}^{-2}\right)$ & Forest type & Location & References \\
\hline \multicolumn{4}{|l|}{ (b) } \\
\hline 3.3 & Lianas in tropical forest & Brazilian Amazon & (Gerwing and Farias, 2000) \\
\hline 3.3 & Lianas in tropical forest & Brazilian Amazon & (Gerwing and Vidal, 2002) \\
\hline 1.7 & Lianas and vines in tropical deciduous forest & Mexico & (Castellanos et al., 1992) \\
\hline 1.2 & Lianas in evergreen tropical rain forest & Rio Negro Basin, Venezuela & (Putz, 1983) \\
\hline 0.7 & Lianas in tropical upland wet forest & Costa Rica & (Clark et al., 2008) \\
\hline$(2-7)$ & Lianas in lowland tropical rain forest & Gabon & (Kazda and Salzer, 2000) \\
\hline \multicolumn{4}{|c|}{1.7 (median), 2.0 (arithmetic mean), 1.2 (standard deviation) } \\
\hline \multicolumn{4}{|c|}{ ( } \\
\hline 5.3 & Mediterranean oak forest & Spain & (Sala et al., 1994) \\
\hline 4.6 & Mediterranean oak forest & Spain & (Sala et al., 1994) \\
\hline 4.3 & Mediterranean evergreen maquis & Portugal & (Caldwell et al., 1986) \\
\hline 2.9 & Coastal oak forest & Bulgaria & (Wiman and Gaydarova, 2008) \\
\hline 2.5 & Mediterranean evergreen maquis & Italy & (Gratani and Varone, 2007) \\
\hline & Mediterranean evergreen maquis & Sardinia, Italy & (Rossi et al., 2001) \\
\hline$(1.4-3.2)$ & Coastal oak forest & Bulgaria & (Gaydarova, 2003) \\
\hline \multicolumn{4}{|c|}{3.6 (median), 3.7 (arithmetic mean), 1.2 (standard deviation) } \\
\hline \multicolumn{4}{|l|}{ (d) } \\
\hline $1.9^{\text {a) }}$ & Douglas fir forest & Oregon coast range, USA & (Weiskittel and Maguire, 2006) \\
\hline $1.3^{\mathrm{a})}$ & Mixed forest & Belgium & (Vincke et al., 2005) \\
\hline $1.3^{\mathrm{b})}$ & Mediterranean oak forest & Spain & (Sala et al., 1994) \\
\hline $0.7^{\mathrm{a})}$ & Tropical dry forest & Mexico, Costa Rica, Brazil & (Sánchez-Azofeifa et al., in press) \\
\hline $0.5^{\mathrm{a})}$ & Tropical dry forest & Mexico, Costa Rica, Brazil & (Sánchez-Azofeifa et al., in press) \\
\hline$(2.0-2.6)^{c)}$ & Rainforests & Japan and Southeast Asia & (Yoneda, 1993) \\
\hline$(0.4-2.5)^{a)}$ & Mixed forest & Alsace, France & (Breda, 2003) \\
\hline$(0.5-1.9)^{c)}$ & Norway spruce forest & Germany & (Falge et al., 1997) \\
\hline$(0.3-1.5)^{a)}$ & Mixed forest & France & (Dufrêne and Bréda, 1995) \\
\hline
\end{tabular}

\footnotetext{
a) WAI

b) SAl, but main trunks excluded

c) $\mathrm{SAl}$
} 
Table A6. Plant surface coverage by EPC on (a) leaves, (b) needles, and (c) stems and branches.

\begin{tabular}{|c|c|c|c|}
\hline Coverage $(\%)$ & EPC components & Location, host plant & Reference \\
\hline \multicolumn{4}{|l|}{ (a) } \\
\hline & Liverworts & Humid tropical forests & (Berrie and Eze, 1975) \\
\hline $\begin{array}{l}>90 \\
(50-100)\end{array}$ & $\begin{array}{l}\text { Bryophytes } \\
\text { Lichens }\end{array}$ & $\begin{array}{l}\text { Tropical lowland rainforest in Costa Rica } \\
\text { Tropical rainforests }\end{array}$ & $\begin{array}{l}\text { (Fürnkranz et al., 2008) } \\
\text { (Anthony et al., 2002) }\end{array}$ \\
\hline$(25-31)$ & Epiphyll cover & Coffee plants, semi-hot humid climate & (Roskoski, 1981) \\
\hline (20-30) (up to 70) & Bryophytes & Rainforest in Costa Rica, understory plants & (Freiberg, 1998, 1999) \\
\hline$(22-35)$ & Lichens & Moist forests of Panama & (Coley et al., 1993) \\
\hline$(2-20)$ & Liverworts & Moist forests of Panama & (Coley et al., 1993) \\
\hline$(2-10)$ & Cyanobacteria & Rainforest in Costa Rica, understory plants & (Freiberg, 1998, 1999) \\
\hline \multicolumn{4}{|l|}{ (b) } \\
\hline 58 & Alectorioid lichens & $\begin{array}{l}\text { Old-growth Pseudotsuga-Tsuga forests, } \\
\text { Pacific Northwest, USA }\end{array}$ & (McCune et al., 1997) \\
\hline $\begin{array}{c}55 \\
27\end{array}$ & Epiphyllic lichen (Hypogymnia physodes) & 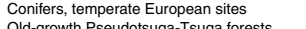 & (Søchting, 1997) \\
\hline & Bryophytes & $\begin{array}{l}\text { Ild-growth Pseudotsuga-Tsuga forests, } \\
\text { Pacific Northwest, USA }\end{array}$ & (McCune et al., 1997) \\
\hline 25 & Various lichens & $\begin{array}{l}\text { Old-growth Pseudotsuga-Tsuga forests, } \\
\text { Pacific Northwest, USA }\end{array}$ & (McCune et al., 1997) \\
\hline 17 & Cyanolichens & $\begin{array}{l}\text { Old-growth Pseudotsuga-Tsuga forests, } \\
\text { Pacific Northwest, USA }\end{array}$ & (McCune et al., 1997) \\
\hline & Actinomycetes, fungi, and algae & Douglas fir, Oregon, USA & (Bernstein and Carroll, 1977) \\
\hline & Microepiphyte cover & Douglas fir, Oregon, USA & \\
\hline & Actinomycetes, fungi, and algae & Douglas fir, Oregon, USA & (Carroll, 1979) \\
\hline$(45-80)$ & Green algae, fungi, and bacteria & Spruce trees, Germany & (Peveling et al., 1992) \\
\hline$(32-77)$ & Epiphytes (chlorolichens, cyanolichens, and bryophytes) & Sitka spruce, California, USA & (Ellyson and Sillett, 2003) \\
\hline \multicolumn{4}{|l|}{ (c) } \\
\hline & Crustose lichens & Lowland forest, Panama & $($ Zotz, 1999) \\
\hline 38 & Crustose lichens & Lowland rainforest, Costa Rica & (Forman, 1975) \\
\hline (40-100) & $\begin{array}{l}\text { Bryophytes (2-14 cm in thickness) } \\
\text { Corticolous and crustose microlichens }\end{array}$ & $\begin{array}{l}\text { Montane rainforests, Ecuador } \\
\text { Atlantic rainforest. Brazil }\end{array}$ & $\begin{array}{l}\text { (Freiberg and Freiberg, 2000) } \\
\text { (Cáceres et a a 2007) }\end{array}$ \\
\hline $\begin{array}{l}\left(\begin{array}{l}3-83)(\text { most between } 20-50) \\
(40-80)\end{array}\right. \\
\text { (a) }\end{array}$ & $\begin{array}{l}\text { Coorticolous and crrustose microlichens } \\
\text { Foliose and crustose lichens }\end{array}$ & $\begin{array}{l}\text { AAlantit rainforest, Brazil } \\
\text { Forest in Norway }\end{array}$ & $\begin{array}{l}\text { (Cáceres et al., 2007) } \\
\text { (Solhaug et al., 1995) }\end{array}$ \\
\hline$(25-60)$ (up to 80$)$ & Mosses, liverworts, cyanolichens and other lichens & Douglas fir, Oregon, USA & (Sherwood and Carroll, 1974; \\
\hline$(2-50)$ & Bryophytes (2-14 cm in thickness) & Lowland rainforests, Ecuador & $\begin{array}{l}\text { Siliett, 19955; ;illett and Rambo, } \\
\text { (Freiberg and Freiberg, 2000) }\end{array}$ \\
\hline
\end{tabular}

Table A7. Annual net carbon uptake by EPC in forest and shrub areas.

\begin{tabular}{lllllll}
\hline Substrate & $\begin{array}{l}\text { Area index } \\
\left(\mathrm{m}^{2} \mathrm{~m}^{-2}\right)\end{array}$ & $\begin{array}{l}\text { Forest/ } \\
\text { shrub area } \\
\left(10^{13} \mathrm{~m}^{2}\right)\end{array}$ & $\begin{array}{l}\text { Plant surface } \\
\text { area } \\
\left(10^{13} \mathrm{~m}^{2}\right)\end{array}$ & $\begin{array}{l}\text { EPC } \\
\text { coverage } \\
(\%)\end{array}$ & $\begin{array}{l}\text { EPC covered } \\
\text { surface area } \\
\left(10^{13} \mathrm{~m}^{2}\right)\end{array}$ & $\begin{array}{l}\text { Annual net carbon } \\
\text { uptake } \\
\left(\mathrm{Pg} \mathrm{a}^{-1}\right)\end{array}$ \\
\hline $\begin{array}{l}\text { Leaves of tropical } \\
\text { evergreen trees }\end{array}$ & 5.4 & $1.7^{\mathrm{b})}$ & 9.2 & 50 & 4.7 & 1.3 \\
$\begin{array}{l}\text { Tropical lianas } \\
\begin{array}{l}\text { Leaves of evergreen trees and } \\
\text { shrubs; temperate and boreal }\end{array}\end{array}$ & $\begin{array}{l}1.7 \\
\begin{array}{l}\text { Stems and branches of } \\
\text { trees and shrubs }\end{array}\end{array}$ & $1.7^{\mathrm{b})}$ & 2.9 & 50 & 1.6 & 0.4 \\
\hline Total & $1.0^{\mathrm{c})}$ & 3.6 & 30 & 1.0 & 0.3 \\
\hline
\end{tabular}

a) see Table A5;

b) see Table A4;

c) from "Community Land Model" (CLM 3.0) (Lawrence and Chase, 2007);

d) estimated from values given in Table A6;

e) calculated assuming a median carbon net fixation rate of $28 \mathrm{~g} \mathrm{~m}^{-2}$ (Table A3). 
Table A8. Estimated global biomass (dry weight) of (a) BSC, (b) BRC, (c, d) EPC. Values in $(\mathrm{a}-\mathrm{c})$ in $\mathrm{g} \mathrm{m}^{-2}$ of ground surface area, (d) in $\mathrm{g} \mathrm{m}^{-2}$ of thallus or branch surface area.

\begin{tabular}{|c|c|c|c|}
\hline Biomass $\left(\mathrm{g} \mathrm{m}^{-2}\right)$ & Component & Location & Reference \\
\hline \multicolumn{4}{|l|}{ (a) } \\
\hline 1187 & Soilcrust cyanolichen (Collema tenax) & Pinyon-juniper woodland, Colorado Plateau, USA & (Lange et al., 1998a) \\
\hline 684 & Chlorolichen (Squamarina lentigera) & Xerothermic steppe formation, Germany & (Lange and Green, 2004) \\
\hline 447 & Lichen of BSC (Teloschistes capensis) & Namib Desert, Namibia & (Lange et al., 2006) \\
\hline & Cyanolichen (Collema cristatum) & Xerothermic steppe formation, Germany & (Lange, 2000b) \\
\hline 258 & Lichen community in dry dwarf shrub heath & Upland Tundra, Brooks Range, Alaska & (Lange et al., 1998b) \\
\hline 219 & Lichen heath & Upland Tundra, Brooks Range, Alaska & (Lange et al., 1998b) \\
\hline & Lichen community in Dryas heath & Upland Tundra, Brooks Range, Alaska & (Lange et al., 1998b) \\
\hline & Lichen-dominated soilcrust (Ramalina maciformis) & Desert mesa, Central Negev Desert, Israel & (Kappen et al., 1980) \\
\hline & Lichen community in moist dwarf shrub heath & Upland Tundra, Brooks Range, Alaska & (Lange et al., 1998b) \\
\hline (1-16) & Edaphic cyanobacteria & $\begin{array}{l}\text { Various locations on Earth } \\
\text {. }\end{array}$ & (Garcia-Pichel et al., 2003) \\
\hline$(1-12)$ & Soil crust cyanobacteria & Various locations, Russia & (Pankratova, 2006) \\
\hline \multicolumn{4}{|c|}{258 (median), 375.3 (arithmetic mean), 362.0 (standard deviation) } \\
\hline \multicolumn{4}{|l|}{ (b) } \\
\hline 594 & Epilithic chlorolichen (Aspicilia radiosa) & Limestone karst plateau, Trieste, Italy & (Tretiach, 1995) \\
\hline 243 & Cyanobacterial biofilm & Inselberg, tropical rainforest, French Guiana & (Dojani et al., 2007) \\
\hline 336 & Endolithic cyanobacteria community & Mt. Falconer, Antarctica & (Büdel et al., 2008) \\
\hline 117 & Endolithic chlorolichen (Verrucaria sp.) & Limestone karst plateau, Trieste, Italy & $\begin{array}{l}\text { (Tretiach, 1995) } \\
\text { (9) }\end{array}$ \\
\hline 50 & Nearly endolithic chloroplichen (Acrocordia conidea) & Limestone karst plateau, Trieste, Italy & (Tretiach, 1995) \\
\hline 50 & Endolithic chlorolichen (Verrucaria marmorea) & Limestone karst plateau, Trieste, Italy & (Tretiach, 1995) \\
\hline 30 & Nearly endolithic chlorolichen (Petractis clausa) & Limestone karst plateau, Trieste, Italy & (Tretiach, 1995) \\
\hline & Endolithic chlorolichen (Rinodina immersa) & Limestone karst plateau, Trieste, Italy & (Tretiach, 1995) \\
\hline (38-185) & Endolithic microbial communities in sandstone & $\begin{array}{l}\text { Mojave Desert, California; Sonoran Desert, } \\
\text { Mexico; Negev Desert, Israel }\end{array}$ & (Friedmann, 1980) \\
\hline (32-177) & Endolithic microbial communities & Beacon sandstone, Dry Valley, Antarctica & (Friedmann, 1980) \\
\hline$(4-107))^{\prime}$ & Endolithic cyanobacteria community & Tshipise sandstone formation, South Africa & (Büdel et al., 2004) \\
\hline$(2-73)$ & Endo- and epilithic algae, cyanonacteria, and lichens & Niagara Escarpment, Ontario, Canada & (Matthes-Sears et al., 1997) \\
\hline
\end{tabular}

Table A8. Continued.

\begin{tabular}{|c|c|c|c|}
\hline Biomass $\left(\mathrm{g} \mathrm{m}^{-2}\right)$ & Component & Location & Reference \\
\hline \multicolumn{4}{|l|}{ (c) } \\
\hline 1013 & $\begin{array}{l}\text { Epiphytic bryophytes (Frullania atrata, } \\
\text { Phyllogonium fulgens) and } \\
\text { epiphyllous algae (Trentepohlia) }\end{array}$ & $\begin{array}{l}\text { Tropical rainforest (at greater depth } \\
\text { within cloud forest canopy), } \\
\text { Guadeloupe, French West Indies }\end{array}$ & (Coxson et al., 1992) \\
\hline 422 & Epiphytic non-crustose lichens and bryophytes & Mt. Baker, Washington, USA & (Rhoades, 1981) \\
\hline 332 & Epiphytic lichens and bryophyts & Old-growth conifer forest, Pacific northwest, USA & (McCune et al., 1997) \\
\hline 221 & $\begin{array}{l}\text { Epiphytic bryophytes (Frullania atrata, } \\
\text { Phyllogonium fulgens) and } \\
\text { epiphyllous algae (Trentepohlia) }\end{array}$ & $\begin{array}{l}\text { Tropical rainforest (upper } 1.5 \mathrm{~m} \text { of } \\
\text { cloud forest canopy), Guadeloupe, } \\
\text { French West Indies }\end{array}$ & (Coxson et al., 1992) \\
\hline 200 & Epiphytic mosses (mainly Hypnum andoi) & Vosges Mountains, France & (Frahm, 2008) \\
\hline 155 & $\begin{array}{l}\text { Epiphytic cyanolichens, alectorioid } \\
\text { and other lichens, and bryophytes }\end{array}$ & $\begin{array}{l}\text { Pseudotsuga, Thuja and Tsuga stands } \\
\text { in Oregon and Washington, USA }\end{array}$ & (McCune, 1993) \\
\hline 125 & $\begin{array}{l}\text { Epiphytic cyanolichens, alectorioid } \\
\text { and other lichens, and bryophytes }\end{array}$ & $\begin{array}{l}\text { Pseudotsuga, Thuja and Tsuga stands } \\
\text { in Oregon and Washington, USA }\end{array}$ & (McCune, 1994) \\
\hline $\begin{array}{l}104 \\
84\end{array}$ & $\begin{array}{l}\text { Epiphytic lichens (dominated by Pseudevernia spp.) } \\
\text { Epiphytic lichens (Lobaria, } \\
\text { Usnea, Hypogymnia, } \\
\text { Alectoria, and Parmelia spp.) }\end{array}$ & $\begin{array}{l}\text { Fir plantation, Massif du Pilat, Loire, France } \\
\text { Conifer, oak and northern hardwood } \\
\text { forests, Canada and USA }\end{array}$ & $\begin{array}{l}\text { (André et al., 1975) } \\
\text { (Pike, 1978) }\end{array}$ \\
\hline 55 & Cyanolichen (Lobaria oregana) & $\begin{array}{l}\text { Douglas fir and western hemlock dominated } \\
\text { forest, Pacific Northwest, USA }\end{array}$ & (Brown and Dalton, 2002) \\
\hline 41 & $\begin{array}{l}\text { Epiphytic lichens (Alectoria spp., } \\
\text { Bryoria spp., and foliose lichens) }\end{array}$ & Entire needle trees, British Columbia, Canada & (Campbell and Coxson, 2001) \\
\hline 1 & Epiphytic noncrustose cyanolichens & $\begin{array}{l}\text { Very moist submontane forest, } \\
\text { (2700 m a.s.l.), Colombia }\end{array}$ & (Forman, 1975) \\
\hline $\begin{array}{l}(63-350) \\
(90-260)\end{array}$ & $\begin{array}{l}\text { Non-crustose lichens and bryophytes } \\
\text { Epiphytic lichens (Alectoria spp., } \\
\text { Bryoria spp., Usnea spp., } \\
\text { fruticose lichens, and cyanolichens) and mosses }\end{array}$ & $\begin{array}{l}\text { Varies forests in USA and Canada } \\
\text { Old-growth Douglas fir forest in Oregon, USA }\end{array}$ & $\begin{array}{l}\text { (Rhoades, 1981) } \\
\text { (Sillett and Rambo, 2000) }\end{array}$ \\
\hline$(108-133)$ & Canopy lichen community & $\begin{array}{l}\text { Wet-temperate rainforest, } \\
\text { British Columbia, Canada }\end{array}$ & (Benson and Coxson, 2002) \\
\hline $\begin{array}{l}(39-50) \\
(<1)\end{array}$ & $\begin{array}{l}\text { Lichen spp. } \\
\text { Epiphytic cyanolichens }\end{array}$ & $\begin{array}{l}\text { Douglas fir forest, Oregon, USA } \\
\text { Gray beech forests, North Carolina, USA }\end{array}$ & $\begin{array}{l}\text { (Becker, 1980) } \\
\text { (Becker, 1980) }\end{array}$ \\
\hline
\end{tabular}


Table A8. Continued.

\begin{tabular}{llll}
\hline Biomass $\left(\mathrm{g} \mathrm{m}^{-2}\right)$ & Component & Location & Reference \\
\hline $\mathbf{( d )}$ & & & \\
\hline $192^{\text {a) }}$ & Lichens (Sticta sp.) & Rainforest, Colombia & (Forman, 1975) \\
$167^{\text {a) }}$ & Lichens with green algae & Rainforest, Colombia & (Forman, 1975) \\
$162^{\text {a) }}$ & Epiphytic cyanolichens & Appalachian Mountains, North Carolina, USA & (Becker, 1980) \\
$153^{\text {a) }}$ & Lichens with non-heterocystic cyanobacteria & Rainforest, Colombia & (Forman, 1975) \\
$151^{\text {a) }}$ & Homoiomerous cyanolichen & Lower montane rainforest, Cordillera Central, & (Lange et al., 2000) \\
& (Leptogium phyllocarpum) & Republic of Panama & \\
$136^{\text {a) }}$ & Lichens (Leptogium sp.) & Rainforest, Colombia & (Forman, 1975) \\
$134^{\text {a) }}$ & Epiphytic Lobariaceae & Lower montane rainforest, Cordillera Central, & (Zotz et al., 1998) \\
& (Sticta tomentosa) & Republic of Panama & \\
$129^{\text {a) }}$ & Homoiomerous cyanolichen & Lower montane rainforest, Cordillera Central, & (Lange et al., 2000) \\
& (Leptogium cyanescens) & Republic of Panama & \\
$105^{\text {a) }}$ & Homoiomerous cyanolichen & Lower montane rainforest, Cordillera Central, & (Lange et al., 2000) \\
& (Leptogium azureum) & Republic of Panama & \\
$70^{\text {a) }}$ & Cyanobacterial basidiolichen & Lower montane rainforest, Cordillera Central, & (Lange et al., 1994a) \\
& (Dictyonema glabratum) & Republic of Panama & \\
$53^{\text {a) }}$ & Corticolous lichen & Tropical evergreen lowland forest, Les & (Lakatos et al., 2006) \\
& (Coenogonium linkii) & Nouragues National Park, French Guiana & \\
$(10-720)^{\text {b) }}$ & Epiphytic lichens and bryophytes & Montane and lowland rainforests, Ecuador & (Freiberg and Freiberg, 2000) \\
\hline 136 (median), 132 (arithmetic mean), 41.7 (standard deviation) & & \\
\hline & & & \\
\hline
\end{tabular}

a) per $\mathrm{m}^{2}$ of thallus surface area;

b) per $\mathrm{m}^{2}$ of branch surface area.

Table A9. Estimated annual fluxes of nitrogen fixation by (a) BSC and (b) EPC.

\begin{tabular}{|c|c|c|c|}
\hline $\begin{array}{l}\text { Nitrogen fixation flux } \\
\left(\mathrm{g} \mathrm{m}^{-2} \mathrm{a}^{-1}\right)\end{array}$ & $\begin{array}{l}\text { Crust } \\
\text { components }\end{array}$ & Location & Reference \\
\hline \multicolumn{4}{|l|}{ (a) } \\
\hline 5.7 & BSC, cyanobacteria & Western Kalahari, Botswana & (Skarpe and Henriksson, 1987) \\
\hline 1.3 & BSC, undisturbed & Cold desert, Utah, USA & (Belnap, 2002) \\
\hline $1.0^{a)}$ & BSC, cyanobacteria & Semiarid grassland, Arizona, USA & (Mayland et al., 1966) \\
\hline 0.6 & BSC, cyanobacteria & Savanna, Nigeria & (Isichei, 1980) \\
\hline 0.4 & BSC, cyanobacterium & Tropical volcano, Guadeloupe & (Sheridan, 1991b) \\
\hline 0.4 & BSC & Lake Michigan sand dunes, USA & (Thiet et al., 2009) \\
\hline 0.2 & Cyanobacteria on soil & Signy Island, South Orkney Islands & (Horne, 1972) \\
\hline 0.14 & BSC, disturbed & Cold desert, Utah, USA & (Belnap, 2002) \\
\hline & BSC & Southern Utah, USA & (Veluci et al., 2006) \\
\hline$(0.2-37)$ & BSC, cyanobacteria and cyanolichens & Desert ecosystems & (Belnap et al., 2001) \\
\hline$(2.5-10.0)$ & BSC, cyanobacteria & Great Basin desert, Utah, USA & (Veluci et al., 2006) \\
\hline$(0.1-10.0)$ & BSC & Various (semi-)arid locations & (Evans and Lange, 2003) \\
\hline$(0.7-1.8)$ & BSC & Sonoran Desert, Arizona, USA & (Veluci et al., 2006) \\
\hline$(0.9-1.3)$ & BSC, undisturbed & Cold desert, Utah, USA & (Belnap, 2002) \\
\hline$(0.1-0.2)$ & Bryophyte-cyanobacteria & Antarctica & (Turetsky, 2003) \\
\hline \multicolumn{4}{|c|}{0.4 (median), 1.1 (arithmetic mean), 1.8 (standard deviation) } \\
\hline \multicolumn{4}{|l|}{ (b) } \\
\hline 42.3 & $\begin{array}{l}\text { EPC, cyanobacteria (Nostoc and } \\
\text { Stigonema spp.) }\end{array}$ & $\begin{array}{l}\text { Mangrove boles and branches, Guadeloupe, } \\
\text { French West Indies }\end{array}$ & (Sheridan, 1991a) \\
\hline 3.8 & $\begin{array}{l}\text { EPC, cyanobacteria (Calothrix } \\
\text { and Lyngbya spp.) }\end{array}$ & $\begin{array}{l}\text { Spartina alterniflora stems, } \\
\text { transplanted salt marsh, North Carolina, USA }\end{array}$ & (Currin and Pearl, 1998) \\
\hline 2.6 & $\begin{array}{l}\text { EPC, cyanobacteria (Calothrix } \\
\text { and Lyngbya spp.) }\end{array}$ & $\begin{array}{l}\text { Spartina alterniflora stems, } \\
\text { natural salt marsh, North Carolina, USA }\end{array}$ & (Currin and Pearl, 1998) \\
\hline $0.5^{\mathrm{b})}$ & $\begin{array}{l}\text { EPC, cyanobacteria (Calothrix } \\
\text { and Anabaena spp.) }\end{array}$ & $\begin{array}{l}\text { Spartina alterniflora leaves and } \\
\text { stems, salt marsh, Georgia, USA }\end{array}$ & (Hanson, 1977) \\
\hline $0.2^{c)}$ & $\begin{array}{l}\text { EPC, cyanobacteria (Calothrix } \\
\text { and Anabaena spp.) }\end{array}$ & $\begin{array}{l}\text { Spartina alterniflora leaves and } \\
\text { stems, salt marsh, Georgia, USA }\end{array}$ & (Hanson, 1977) \\
\hline 0.2 & $\begin{array}{l}\text { EPC, symbiotic cyanobacterium (Nostoc sp.) } \\
\text { within feather moss (Pleurozium schreberi) }\end{array}$ & Boreal forests & (DeLuca et al., 2002) \\
\hline 0.2 & Epiphytic lichens & $\begin{array}{l}\text { Old-growth Douglas fir forest } \\
\text { of Pacific Northwest, USA }\end{array}$ & (Brown and Dalton, 2002) \\
\hline 0.15 & $\begin{array}{l}\text { Epiphytic cyanolichens } \\
\text { (Lobaria oregana) }\end{array}$ & $\begin{array}{l}\text { Pseudotsuga, Thuja and Tsuga } \\
\text { stands (WRCC site), Washington, USA }\end{array}$ & (Antoine, 2004) \\
\hline $\begin{array}{l}(0-6) \\
(0.3-1.7)\end{array}$ & $\begin{array}{l}\text { EPC } \\
\text { Epiphytic cyanolichens } \\
\text { (Lobaria oregana) }\end{array}$ & $\begin{array}{l}\text { Temperate and tropical regions } \\
\text { Pseudotsuga, Thuja and Tsuga } \\
\text { stands (HJA site), Washington, USA }\end{array}$ & $\begin{array}{l}\text { (Freiberg, 1998) } \\
\text { (Antoine, 2004) }\end{array}$ \\
\hline $\begin{array}{l}(0.2-0.8) \\
(0.2-0.5)\end{array}$ & $\begin{array}{l}\text { Epiphytic lichens } \\
\text { Understory EPC, cyanobacteria }\end{array}$ & $\begin{array}{l}\text { Rainforest in Colombia ( } 2700 \text { m a.s.l.) } \\
\text { Premontane rainforest in Costa Rica }\end{array}$ & $\begin{array}{l}\text { (Forman, 1975) } \\
\text { (Freiberg, 1998) }\end{array}$ \\
\hline$(0.1-0.5)$ & Epiphytic lichens & Scotland and Sweden & (Forman, 1975) \\
\hline
\end{tabular}

a) maximum; ${ }^{\text {b) }}$ average from control and experimental plot $-10 \mathrm{~h}$ fixation period estimate; ${ }^{c)}$ average from control and experimental plot -24 hour fixation period estimate. 


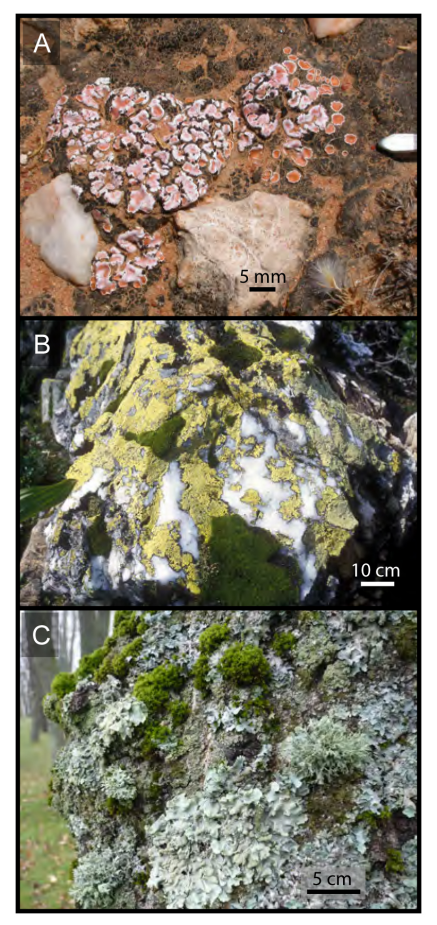

Fig. 1. Exemplary photographs of microbiotic crusts. (A) Biological soil crust (BSC) showing cyanobacteria and chlorolichen Psora decipiens, Nama Karoo semi desert, Western Cape, South Africa. (B) Biological rock crust (BRC) showing chlorolichen (Rhizocarpon geographicum aggr.), Sadnig, Eastern Alps, Austria. (C) Epiphytic crust (EPC) showing lichen and bryophytes on Acer pseudoplatanus tree in a city park, Trier, Germany. 